Article

\title{
Interactions between Indigenous Endophyte Bacillus subtilis L1-21 and Nutrients inside Citrus in Reducing Huanglongbing Pathogen Candidatus Liberibacter Asiaticus
}

\author{
Suhail Asad ${ }^{1,+}{ }^{,}$Pengbo He ${ }^{1,+}{ }^{+}$, Pengfei He ${ }^{1}$, Yongmei $\mathrm{Li}^{1}$, Yixin $\mathrm{Wu}^{1,2}$, Ayesha Ahmed ${ }^{1}$, Yunyue Wang ${ }^{1}$, \\ Shahzad Munir ${ }^{1, *}$ (D) and Yueqiu He ${ }^{1, *}$ \\ 1 State Key Laboratory for Conservation and Utilization of Bio-Resources in Yunnan, \\ Yunnan Agricultural University, Kunming 650201, China; sohailasad74@gmail.com (S.A.); \\ pengbohe@126.com (P.H.); nanhudaozhu@163.com (P.H.); kala.111@163.com (Y.L.); WY68579@126.com (Y.W.); \\ aisha_ahmed01@hotmail.com (A.A.); yunyuewang@126.com (Y.W.) \\ 2 Faculty of Agronomy and Biotechnology, Yunnan Agricultural University, Kunming 650201, China \\ * Correspondence: shahzad_munir@ynau.edu.cn (S.M.); ynfh2007@163.com (Y.H.) \\ + These authors have contributed equally to this work and share first authorship.
}

\section{check for}

updates

Citation: Asad, S.; He, P.; He, P.; Li, Y.; Wu, Y.; Ahmed, A.; Wang, Y.; Munir, S.; He, Y. Interactions between Indigenous Endophyte Bacillus subtilis L1-21 and Nutrients Inside Citrus in Reducing Huanglongbing Pathogen Candidatus Liberibacter Asiaticus. Pathogens 2021, 10, 1304. https://doi.org/10.3390/pathogens 10101304

Academic Editor: Giovanni Bubici

Received: 8 August 2021

Accepted: 6 October 2021

Published: 12 October 2021

Publisher's Note: MDPI stays neutral with regard to jurisdictional claims in published maps and institutional affiliations.

Copyright: (c) 2021 by the authors Licensee MDPI, Basel, Switzerland. This article is an open access article distributed under the terms and conditions of the Creative Commons Attribution (CC BY) license (https:// creativecommons.org/licenses/by/ $4.0 /)$
Abstract: Huanglongbing (HLB) pathogen Candidatus Liberibacter asiaticus (CLas) brings a great concern about the phloem nutrient transport in diseased plants. There is an urgent need to find the best management strategies to reduce the losses in the citrus industry worldwide. Endophytic bacteria are negatively affected by CLas pathogen, and these endophytes are associated with improved availability of nutrients and pathogen resistance. This study underpins the relationship between CLas pathogen, endophyte population and nutrients availability in citrus plants. The citrus plants were treated with Bacillus subtilis L1-21 and Hoagland solution to find out synergism efficacy to mitigate citrus HLB. We showed that citrus shoots in the presence of 50\% Hoagland solution displayed maximum number of endophytes with $6.28 \times 10^{3}$ to $3.04 \times 10^{5} \mathrm{CFU} / \mathrm{g}$. Among 50 candidate strains, B. subtilis L1-21 emerged as potential antagonist against surrogate strain Xanthomonas citri subsp. citri. The citrus half-leaf method identified that application of endophyte L1-21 with 50\% Hoagland solution successfully reduces the CLas abundance. We point out that this combination results in a higher number of endophytes population with $2.52 \times 10^{4}$ to $9.11 \times 10^{6} \mathrm{CFU} / \mathrm{g}$ after 60 days, and reduces CLas pathogen abundance in asymptomatic HLB plants. In HLB symptomatic citrus plants, B. subtilis L1-21 potentially increases the endophyte population from $1.11 \times 10^{4}$ to $5.26 \times 10^{7} \mathrm{CFU} / \mathrm{g}$ in the presence of Hoagland solution, and pathogen abundance was reduced from $9.51 \times 10^{5}$ to $1.06 \times 10^{4}$ copies $/ g$. Altogether, we suggested that the presence of endophyte L1-21 with Hoagland solution is more effective in HLB asymptomatic citrus plants, but a slight reduction of pathogen was observed in symptomatic plants. The findings revealed the role of indigenous citrus endophyte B. subtilis L1-21 along with other nutrients in the reduction of CLas pathogen abundance inside symptomatic and asymptomatic plants in citrus endophyte-nutrient-pathogen interplay.

Keywords: Candidatus Liberibacter asiaticus; endophyte; citrus Huanglongbing; nutrients; Bacillus subtilis L1-21

\section{Introduction}

Citrus greening disease, commonly known as citrus Huanglongbing (HLB) is one of the most devastating citrus diseases causes extreme economic losses globally [1]. The disease-causing pathogens are non-culturable, fastidious, phloem-restricted $\alpha$-proteobacteria named as Candidatus Liberibacter asiaticus (CLas), Candidatus Liberibacter americanus (CLam), and Candidatus Liberibacter africanus (CLaf) based on their origin [1-3]. The vector responsible for transmission of pathogens is Asian citrus psyllid, known as Diaphorina citri [4]. In diseased plants, pathogen moves into the phloem of the citrus leaves and causes sieve plug formation and accumulation. Subsequently, this accumulation alters the 
metabolism of carbohydrates and blocks nutrient transport result in phenotypic changes to the citrus tree in the form of reduced root growth, blotchy, and yellow mottles on the leaves $[5,6]$. The distribution of HLB pathogen is highly patchy, as most of the bacterial titers can be found in the leaf midribs, diseased roots and stems [7,8].

Of interest is the difficulty in HLB symptoms diagnosis [9], specially, leaf symptoms of HLB infected citrus plants could be confused with that of nutrient deficiency at early stage of infection [10-12]. At initial stage of HLB infection, leaf symptoms resemble with $\mathrm{Zn}, \mathrm{Fe}$, and $\mathrm{Mg}$ deficiencies [7,13]. Later severe symptoms as enlarged, swollen, and corky leaf veins resemble B deficiency [12]. Moreover, some of those symptoms are related to starch accumulation in leaves [9], resembling with $\mathrm{Ca}, \mathrm{Mg}$ and $\mathrm{Zn}$ deficiencies [14,15]. HLB-affected sweet orange leaves (Citrus sinensis) reported lower amount of $\mathrm{K}, \mathrm{Ca}, \mathrm{Mg}$, $\mathrm{Cu}, \mathrm{Fe}, \mathrm{Zn}, \mathrm{Mn}$, and B as compare to healthy leaves $[6,15,16]$.

Endophytes live asymptomatically inside plant building the microbiome and share most intimate association with their host. They are even regarded as extended genomes of plant for the virtues they perform for plant health and safety. Employment of indigenous endophytes isolated from healthy state to engineer the diseased citrus endophytic microbiomes that can provide sustainable solution for vascular pathogens $[17,18]$.

To date, endophyte-mediated resistance always emerge as an exciting possibility to manage different diseases in the labs and field experiments [19]. One long standing proposed role of endophytic bacteria in plant disease control is to assist the plant to uptake nutrients, improve stress tolerance and provide pathogen resistance [20-22]. Pathogen resistance activities are associated with secondary metabolites production, antibiotics or chitinase enzyme that can inhibit the growth of plant pathogens. All of these studies support the idea of using indigenous endophytes as potential antagonist. Their effective use will reduce the dependence on chemical fertilizers and pesticides [23]. Keeping the importance of previous studies in citrus plants using endophyte L1-21, remarkable changes were observed in healthy and diseased citrus plants [24]. Metabolomics approaches were conducted to gain information about the molecular mechanism of citrus plant to defend themselves against CLas [25]. This strain inoculation to the postharvest gray mold of tomato considerably reduces the pathogen Botrytis cinerea [25,26]. Therefore, the main goal of this study was to assess disease-nutrient model for comparing HLB symptoms with nutrient deficiency in the presence of endophyte B. subtilis L1-21, to study the relationship between symptoms of citrus HLB and nutritional deficiency and to examine the role of endophytes to reduce the CLas pathogen abundance and nutritional availability.

\section{Results}

\subsection{Effect of Hoagland Solution on Citrus Endophytic Population in Citrus Shoots}

The effect of different concentrations (50\%, 75\% and 100\%) of Hoagland solution on endophytes population in citrus shoots indicated that treatment of $50 \%$ Hoagland solution significantly increased the number of endophytes in citrus shoots $\left(6.28 \times 10^{3}\right.$ to $\left.3.04 \times 10^{5} \mathrm{CFU} / \mathrm{g}\right)$ followed by $75 \%\left(4.06 \times 10^{3}\right.$ to $\left.9.22 \times 10^{3} \mathrm{CFU} / \mathrm{g}\right)$. The increase concentration of tested solution $(100 \%)$ did not change the endophyte population inside citrus shoots and it was found to be stable at $10^{3} \mathrm{CFU} / \mathrm{g}$ of citrus leaves. No difference of endophyte population $\left(10^{3} \mathrm{CFU} / \mathrm{g}\right.$ in all three) was found among the two concentration of Hoagland solution (75 and 100\%) and the control (Figure 1).

\subsection{Antagonistic Effect of Different Bacillus sp. against Xanthomonas citri subsp. citri}

The 50 candidate strains isolated in our study were tested for suppression efficiency against surrogate strain Xanthomonas citri subsp. citri. We suggested that among all of these tested endophytic strains, six strains (Bacillus subtilis YN-003, B. subtilis YN-012, B. spizizenii YN-016, B. subtilis YN-024, and B. subtilis YN-033 and B. subtilis L1-21) displayed significant antagonistic activities against $X$. citri subsp. citri. The results indicated that endophyte $B$. subtilis L1-21 was found to have maximum inhibition zone between other treatments. The 
growth inhibition ratio (GIR) of B. subtilis L1-21 (0.63\%) was higher than the other Bacillus species (Table 1).

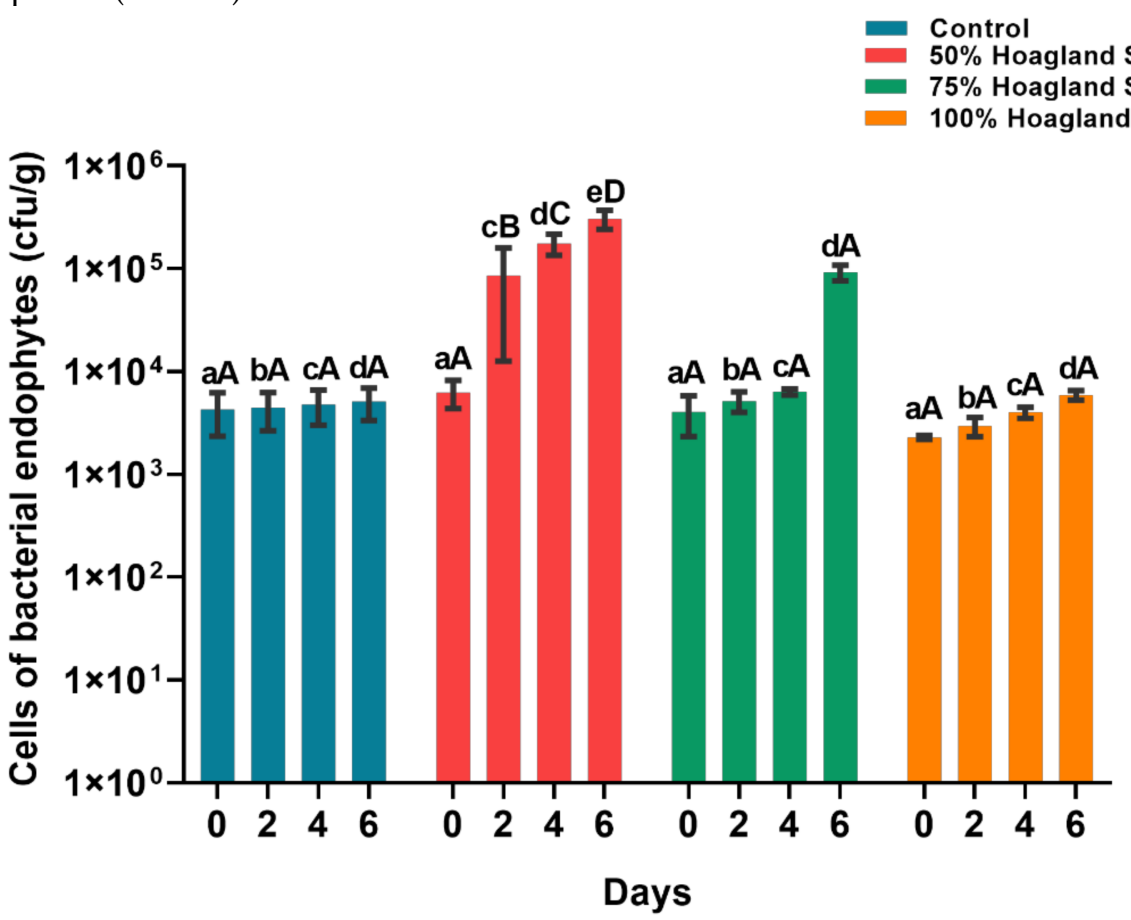

Figure 1. Population dynamics of endophytes in citrus shoots before and after application of different concentrations of Hoagland solution $(50 \%, 75 \%, 100 \%)$ and control $\left(\mathrm{ddH}_{2} \mathrm{O}\right)$. Data were analyzed using analysis of variance (ANOVA) followed by Duncan's multiple range test $(p<0.05)$. Different letters on top indicate significant differences between different treatment and error bars indicate the standard error of the mean (SEM). Small letters $(\mathrm{abc})$ denote the difference between groups at same day, while capital letters $(\mathrm{A}, \mathrm{B}, \mathrm{C})$ indicate the difference within same group at different days. Each treatment consists of three replicates and each replicates consist of 6 citrus shoots.

Table 1. Antagonistic effect of selected Bacillus isolates against Xanthomonas citri subsp. citri.

\begin{tabular}{cccc}
\hline Bacillus Species & $\begin{array}{c}\text { Inhibition Diameter } \\
(\mathbf{m m})\end{array}$ & $\begin{array}{c}\text { Colony Diameter } \\
(\mathbf{m m})\end{array}$ & $\begin{array}{c}\text { Growth Inhibition Ratio } \\
\mathbf{( \% )}\end{array}$ \\
\hline B. subtilis YN-003 & $18.66 \pm 0.15$ & $11.33 \pm 0.15$ & $0.39 \pm 0.007 \mathrm{~b}$ \\
B. subtilis YN-012 & $17.66 \pm 0.15$ & $11.33 \pm 0.15$ & $0.36 \pm 0.014 \mathrm{~b}$ \\
B. spizizenii YN-016 & $15.33 \pm 0.15$ & $11.33 \pm 0.15$ & $0.26 \pm 0.015 \mathrm{c}$ \\
B. subtilis YN-024 & $12.66 \pm 0.15$ & $9.66 \pm 0.15$ & $0.23 \pm 0.019 \mathrm{c}$ \\
B. subtilis YN-033 & $15.33 \pm 0.15$ & $10.33 \pm 0.15$ & $0.33 \pm 0.014 \mathrm{c}$ \\
B. subtilis L1-21 & $24.33 \pm 0.15$ & $9.00 \pm 0.26$ & $0.63 \pm 0.009 \mathrm{a}$ \\
\hline
\end{tabular}

Significance difference $(p<0.05)$ between growth inhibitions ratios $(\%)$ of different isolated strains are indicated by different letters according to Duncan's Multiple Range Test at $p<0.05$ of three replicates. Growth inhibition ratio $=[($ Inhibition zone diameter - Colony diameter $) /$ Inhibition zone diameter $] \times 100$.

\subsection{Effect of Bacillus sp. and Hoagland Solution on CLas Abundance by Using Half-Leaf Method}

To further associate the use of endophyte and nutrients solution, the citrus halfleaf method enabled our understanding about pathogen reduction in one half of leaf, while the other half was kept as control. The experiment revealed that endophytic bacteria B. subtilis $\mathrm{YN}-003$, B, subtilis $\mathrm{YN}-012$, B. spizizenii $\mathrm{YN}-016$, B. subtilis $\mathrm{YN}-033$ and $B$. subtilis L1-21 with combination of Hoagland solution significantly reduce the CLas abundance from initial pathogen abundance of $1.47 \times 10^{6}, 5.96 \times 10^{5}, 6.21 \times 10^{4}, 9.29 \times 10^{6}$, $1.65 \times 10^{5}$ to $9.11 \times 10^{5}, 4.48 \times 10^{5}, 4.16 \times 10^{3}, 1.17 \times 10^{6}, 7.52 \times 10^{3}$, respectively (Table 2). Maximum pathogen reduction was recorded after 4 days in the endophyte $B$. subtilis L1-21 combination with Hoagland solution highlights the considerable reduction of CLas pathogen (Table 2). 
Table 2. Number of pathogen abundance of CLas in HLB-affected citrus leaves before and after treatment of candidate Bacillus sp. with and without combination of Hoagland solution by using half leaf method.

\begin{tabular}{|c|c|c|c|c|c|c|}
\hline \multirow{2}{*}{ Treatment } & \multirow{2}{*}{ Leaf Samples } & \multicolumn{5}{|c|}{ Pathogen Abundance/g } \\
\hline & & 0 Day & 1st Day & 2nd Day & 3rd Day & 4th Day \\
\hline \multirow{4}{*}{$\mathrm{T} 1$} & $0-1$ & $8.72 \times 10^{6}$ & $1.27 \times 10^{5}$ & & & \\
\hline & $0-2$ & $6.47 \times 10^{5}$ & & $1.09 \times 10^{4}$ & & \\
\hline & $0-3$ & $5.24 \times 10^{5}$ & & & $3.34 \times 10^{5}$ & \\
\hline & $0-4$ & $9.48 \times 10^{5}$ & & & & $8.79 \times 10^{5}$ \\
\hline \multirow{4}{*}{$\mathrm{T} 2$} & $0-1$ & $9.33 \times 10^{5}$ & $1.80 \times 10^{5}$ & & & \\
\hline & $0-2$ & $4.17 \times 10^{5}$ & & $3.32 \times 10^{5}$ & & \\
\hline & $0-3$ & $1.34 \times 10^{5}$ & & & $1.11 \times 10^{5}$ & \\
\hline & $0-4$ & $1.47 \times 10^{6}$ & & & & $9.11 \times 10^{5}$ \\
\hline \multirow{4}{*}{ T3 } & $0-1$ & $2.65 \times 10^{5}$ & $4.12 \times 10^{4}$ & & & \\
\hline & $0-2$ & $7.52 \times 10^{4}$ & & $5.75 \times 10^{4}$ & & \\
\hline & $0-3$ & $3.25 \times 10^{5}$ & & & $2.53 \times 10^{4}$ & \\
\hline & $0-4$ & $3.11 \times 10^{5}$ & & & & $5.24 \times 10^{4}$ \\
\hline \multirow{4}{*}{$\mathrm{T} 4$} & $0-1$ & $8.76 \times 10^{5}$ & $1.01 \times 10^{5}$ & & & \\
\hline & $0-2$ & $5.71 \times 10^{5}$ & & $3.29 \times 10^{5}$ & & \\
\hline & $0-3$ & $5.89 \times 10^{5}$ & & & $2.66 \times 10^{5}$ & \\
\hline & $0-4$ & $5.96 \times 10^{5}$ & & & & $4.48 \times 10^{5}$ \\
\hline \multirow{4}{*}{ T5 } & $0-1$ & $6.58 \times 10^{5}$ & $4.34 \times 10^{5}$ & & & \\
\hline & $0-2$ & $8.56 \times 10^{6}$ & & $6.12 \times 10^{6}$ & & \\
\hline & $0-3$ & $9.82 \times 10^{6}$ & & & $5.82 \times 10^{6}$ & \\
\hline & $0-4$ & $2.76 \times 10^{6}$ & & & & $9.33 \times 10^{5}$ \\
\hline \multirow{4}{*}{ T6 } & $0-1$ & $1.03 \times 10^{6}$ & $8.54 \times 10^{5}$ & & & \\
\hline & $0-2$ & $7.41 \times 10^{5}$ & & $3.09 \times 10^{5}$ & & \\
\hline & $0-3$ & $1.48 \times 10^{6}$ & & & $4.20 \times 10^{5}$ & \\
\hline & $0-4$ & $6.21 \times 10^{4}$ & & & & $4.16 \times 10^{3}$ \\
\hline \multirow{4}{*}{$\mathrm{T} 7$} & $0-1$ & $5.12 \times 10^{5}$ & $3.03 \times 10^{5}$ & & & \\
\hline & $0-2$ & $2 \times 10^{4}$ & & $1.55 \times 10^{4}$ & & \\
\hline & $0-3$ & $2.58 \times 10^{6}$ & & & $9.48 \times 10^{5}$ & \\
\hline & $0-4$ & $3.01 \times 10^{5}$ & & & & $1.34 \times 10^{5}$ \\
\hline \multirow{4}{*}{$\mathrm{T} 8$} & $0-1$ & $2.03 \times 10^{5}$ & $2.56 \times 10^{4}$ & & & \\
\hline & $0-2$ & $1.31 \times 10^{6}$ & & $1.22 \times 10^{6}$ & & \\
\hline & $0-3$ & $8.68 \times 10^{5}$ & & & $5.72 \times 10^{5}$ & \\
\hline & $0-4$ & $9.29 \times 10^{6}$ & & & & $1.17 \times 10^{6}$ \\
\hline \multirow{4}{*}{ T9 } & $0-1$ & $5.14 \times 10^{6}$ & $2.86 \times 10^{5}$ & & & \\
\hline & $0-2$ & $2.62 \times 10^{6}$ & & $2.83 \times 10^{5}$ & & \\
\hline & 03 & $9.41 \times 10^{5}$ & & & $8.58 \times 10^{4}$ & \\
\hline & $0-4$ & $6.71 \times 10^{4}$ & & & & $6.16 \times 10^{3}$ \\
\hline
\end{tabular}


Table 2. Cont.

\begin{tabular}{|c|c|c|c|c|c|c|}
\hline \multirow{2}{*}{ Treatment } & \multirow{2}{*}{ Leaf Samples } & \multicolumn{5}{|c|}{ Pathogen Abundance/g } \\
\hline & & 0 Day & 1st Day & 2nd Day & 3rd Day & 4th Day \\
\hline \multirow{4}{*}{$\mathrm{T} 10$} & $0-1$ & $6.19 \times 10^{6}$ & $2.63 \times 10^{6}$ & & & \\
\hline & $0-2$ & $1.07 \times 10^{6}$ & & $1.60 \times 10^{5}$ & & \\
\hline & $0-3$ & $1.65 \times 10^{6}$ & & & $8.16 \times 10^{5}$ & \\
\hline & $0-4$ & $1.65 \times 10^{5}$ & & & & $7.52 \times 10^{3}$ \\
\hline \multirow{4}{*}{$\mathrm{T} 11$} & $0-1$ & $7.78 \times 10^{6}$ & $5.21 \times 10^{6}$ & & & \\
\hline & $0-2$ & $6.47 \times 10^{6}$ & & $5.19 \times 10^{6}$ & & \\
\hline & $0-3$ & $8.77 \times 10^{5}$ & & & $8.06 \times 10^{5}$ & \\
\hline & $0-4$ & $4.66 \times 10^{6}$ & & & & $4.12 \times 10^{6}$ \\
\hline \multirow{4}{*}{$\mathrm{T} 12$} & $0-1$ & $3.57 \times 10^{5}$ & $6.43 \times 10^{5}$ & & & \\
\hline & $0-2$ & $8.43 \times 10^{5}$ & & $8.33 \times 10^{6}$ & & \\
\hline & $0-3$ & $5.20 \times 10^{6}$ & & & $5.05 \times 10^{6}$ & \\
\hline & $0-4$ & $5.15 \times 10^{5}$ & & & & $7.27 \times 10^{5}$ \\
\hline
\end{tabular}

Pathogen abundance in each sample were calculated using standard curve used in our previous study [27]. Every treatment consists of three replications and each replicates consist of 12 citrus leaves used for midribs analysis from which the pathogen abundance was calculated. $\mathrm{T} 1=$ Bacillus subtilis $\mathrm{YN}-003, \mathrm{~T} 2=$ B. subtilis $\mathrm{YN}-003+$ Hoagland solution, $\mathrm{T} 3=$ B. subtilis $\mathrm{YN}-012, \mathrm{~T} 4=$ B. subtilis $\mathrm{YN}-012+$ Hoagland solution, T5 = B. spizizenii YN-016, T6 = B. spizizenii YN-016 + Hoagland solution, T7 = B. subtilis $\mathrm{YN}-033, \mathrm{~T} 8=$ B. subtilis $\mathrm{YN}-033$, $\mathrm{T} 9=$ B. subtilis $\mathrm{L} 1-21, \mathrm{~T} 10=$ B. subtilis $\mathrm{L} 1-21+$ Hoagland solution, $\mathrm{T} 11=$ Hoagland solution, $\mathrm{T} 12=\mathrm{Control}\left(\mathrm{ddH}_{2} \mathrm{O}\right), 0-1,0-2,0-3,0-4$ means leaf samples at 0 Day.

2.4. Bacillus Subtilis L1-21 Successfully Reduce the Pathogen Inside Asymptomatic Citrus Plants in the Presence of Hoagland Solution

Foliar application of different treatments (50\% Hoagland solution, 50\% Hoagland solution $+B$. subtilis L1-21, B. subtilis L1-21) on asymptomatic Cirtus limon plants grown in greenhouse showed considerable pathogen reduction. We showed maximum number of endophyte population varies from $2.52 \times 10^{4}$ to $9.11 \times 10^{6} \mathrm{CFU} / \mathrm{g}$ when the citrus plants were treated with endophyte L1-21 and nutrient Hoagland solution. The application of Hoagland solution and B. subtilis alone results in endophyte dynamic of $2.15 \times 10^{4}$ to $1.38 \times 10^{5}$ and $2.30 \times 10^{4}$ to $7.01 \times 10^{5} \mathrm{CFU} / \mathrm{g}$, respectively) (Figure 2). Although, the number of endophytes increased considerably in asymptomatic plants by application of different treatments. However, it's also necessary to know the impact of endophyte population in reduction of pathogen abundance. Meanwhile, leaf samples were collected to check pathogen abundance through real time qPCR analysis with a 20 days interval. After 60 days, results indicated that citrus plants treated with $50 \%$ Hoagland solution $+B$. subtilis L1-21 reduced the pathogen abundance up to $91.43 \%$ from $3.20 \times 10^{2}$ to $2.74 \times 10^{1}$ compared with the treatment of Hoagland solution and endophyte L1-21 alone range from $\left(5.46 \times 10^{2}\right.$ to $1.69 \times 10^{2}, 5.13 \times 10^{2}$ to $4.12 \times 10^{2}$, and $2.95 \times 10^{2}$ to $9.57 \times 10^{2} \mathrm{CFU} / \mathrm{g}$, respectively) (Table 3$)$. 


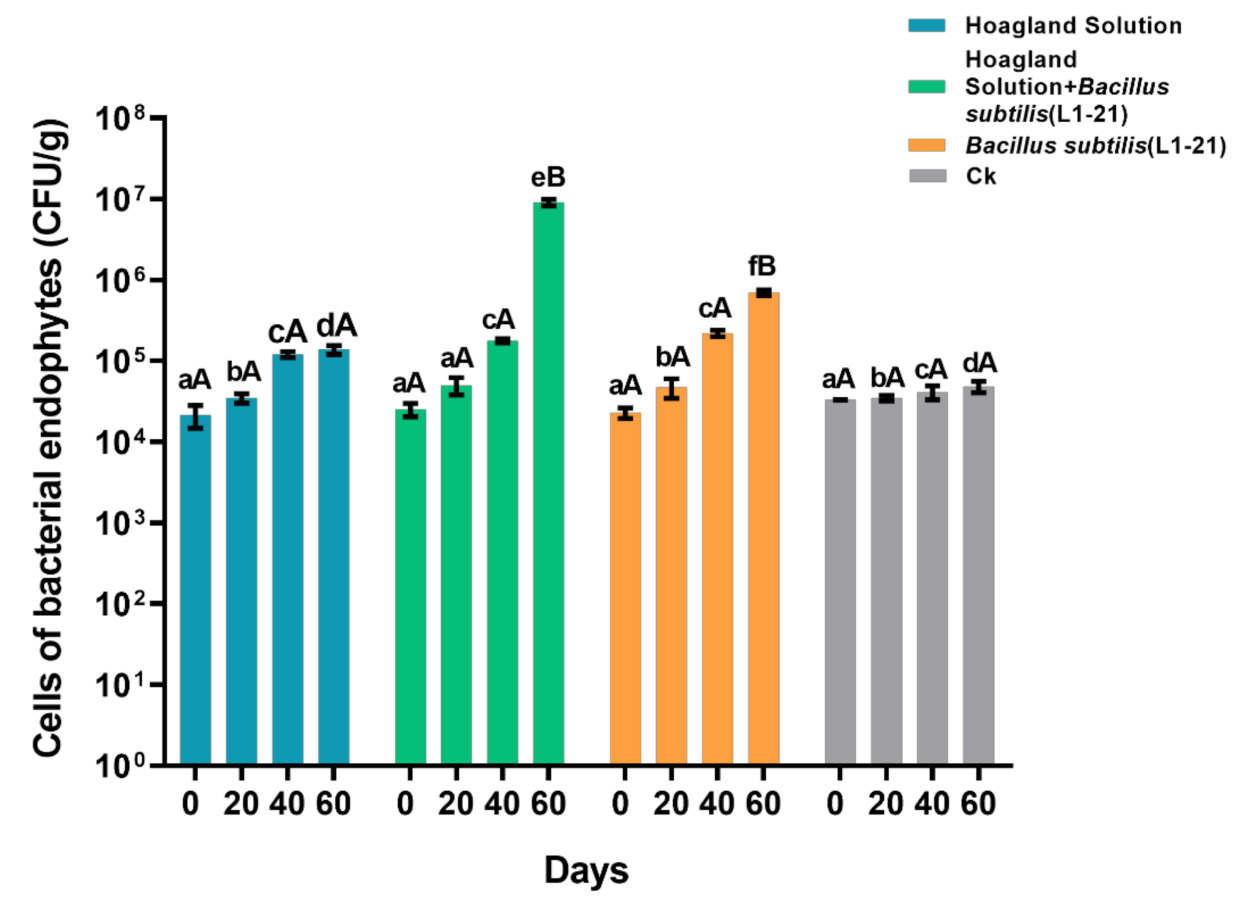

Figure 2. Population dynamics of endophytes in HLB asymptomatic citrus plants before and after application of different treatments (50\% Hoagland solution, 50\% Hoagland solution+ B. subtilis L1-21, B. subtilis L1-21 and control $\left(\mathrm{ddH}_{2} \mathrm{O}\right)$ ). Data were analyzed using analysis of variance (ANOVA) followed by Duncan's multiple range test $(p<0.05)$. Different letters on top indicate significant differences between different treatment and error bars indicate the standard error of the mean (SEM). Small letters $(\mathrm{abc})$ denote the difference between groups at same day, while capital letters $(\mathrm{A}, \mathrm{B}, \mathrm{C})$ indicate the difference within same group at different days.

Table 3. Pathogen abundance of CLas in HLB asymptomatic citrus plants after foliar application of Bacillus subtilis L1-21 and Hoagland solution.

\begin{tabular}{cccccccccc}
\hline & & \multicolumn{2}{c}{ 0 Day } & \multicolumn{2}{c}{ 20 Day } & \multicolumn{2}{c}{ 40 Day } \\
\cline { 3 - 8 } Sr & Treatment & Ct Value & $\begin{array}{c}\text { Pathogen } \\
\text { Abundance }\end{array}$ & Ct Value & $\begin{array}{c}\text { Pathogen } \\
\text { Abundance }\end{array}$ & Ct Value & $\begin{array}{c}\text { Pathogen } \\
\text { Abundance }\end{array}$ & Ct Value & $\begin{array}{c}\text { Pathogen } \\
\text { Abundance }\end{array}$ \\
\hline T1 & $\begin{array}{c}50 \% \text { Hoagland } \\
\text { solution }\end{array}$ & $30.20 \pm 0.003$ & $5.13 \times 10^{2}$ & $30.38 \pm 0.022$ & $4.12 \times 10^{2}$ & $30.52 \pm 0.023$ & $4.12 \times 10^{2}$ & $31.24 \pm 0.025$ & $4.12 \times 10^{2}$ \\
\hline T2 & $\begin{array}{c}50 \% \text { HS + B. } \\
\text { subtilis L1-21 }\end{array}$ & $30.64 \pm 0.012$ & $3.20 \times 10^{2}$ & $31.96 \pm 0.024$ & $1.42 \times 10^{2}$ & $33.69 \pm 0.003$ & $1.42 \times 10^{2}$ & $34.588 \pm 0.017$ & $2.74 \times 10^{1}$ \\
\hline T3 & B. subtilis L1-21 & $30.02 \pm 0.013$ & $5.46 \times 10^{2}$ & $31.57 \pm 0.009$ & $1.69 \times 10^{2}$ & $32.48 \pm 0.016$ & $1.69 \times 10^{2}$ & $33.79 \pm 0.008$ & $1.69 \times 10^{2}$ \\
\hline T4 & Control(ddH $\left.{ }_{2} \mathrm{O}\right)$ & $30.69 \pm 0.009$ & $2.95 \times 10^{2}$ & $29.54 \pm 0.016$ & $9.57 \times 10^{2}$ & $28.66 \pm 0.004$ & $9.57 \times 10^{2}$ & $27.73 \pm 0.009$ & $9.57 \times 10^{2}$ \\
\hline
\end{tabular}

$\mathrm{Ct}=$ Cycle threshold. HS = Hoagland solution. Pathogen abundance in each sample was calculated through standard curve used in our previous study [27]. Every treatment consists of three replications and each replicate consists of 3 citrus plants (3 years old).

\subsection{Slight Pathogen Reduction in Symptomatic Citrus Plants in the Presence of Hoagland Solution + Bacillus subtilis L1-21}

Besides treatment in asymptomatic citrus plants, same applications were also tested in symptomatic C. limon plants. Similar trends of maximum endophyte population were found in the plants treated with $50 \%$ Hoagland solution+ B. subtilis L1-21 range from $1.11 \times 10^{4}$ to $5.26 \times 10^{7} \mathrm{CFU} / \mathrm{g}$. In contrast, treatment with $B$. subtilis L1-21, and $50 \%$ Hoagland solution represents the endophyte population as $3.81 \times 10^{4}$ to $6.26 \times 10^{7}$, and $1.19 \times 10^{4}$ to $1.12 \times 10^{6} \mathrm{CFU} / \mathrm{g}$, respectively (Figure 3). The endophyte increase led to pathogen reduction in diseased citrus plants, as we highlighted that endophyte L1-21 and Hoagland solution combination reduces that pathogen abundance to $98.88 \%$ after 60 days, which are not significantly different from the endophyte L1-21 treatment alone $(97.45 \%)$. The Hoagland solution applied independently slightly reduce the CLas pathogen with $41.38 \%$ 
(Table 4). HLB-affected citrus plant treated with B. subtilis L1-21 have changed leaf color and improved the growth with reduction of $C$ Las titer (Data not shown). The experiment results concluded that $B$. subtilis L1-21 have possible effect on Hoagland solution with stable concentration in order to increase the endophyte population and reduce the CLas pathogen, but how the endophyte interaction is involved in the present of these nutrient solution need to study in future work.

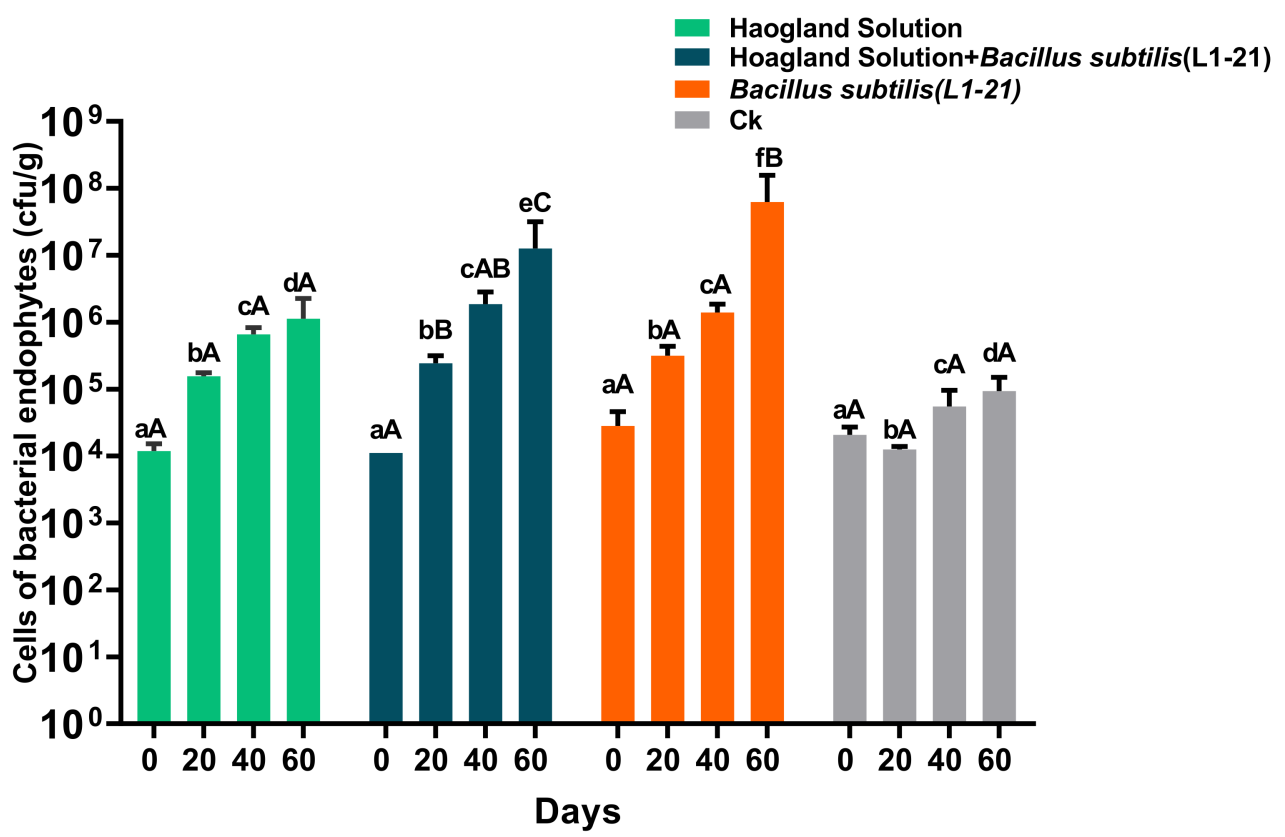

Figure 3. Population dynamics of endophytes in HLB symptomatic citrus plants before and after application of different treatments (50\% Hoagland solution, 50\% Hoagland solution+ B. subtilis L1-21, B. subtilis L1-21 and control $\left.\left(\mathrm{ddH}_{2} \mathrm{O}\right)\right)$. Data were analyzed using analysis of variance (ANOVA) followed by Duncan's multiple range test $(p<0.05)$. Different letters on top indicate significant differences between different treatment and error bars indicate the standard error of the mean (SEM). Small letters $(\mathrm{abc})$ denote the difference between groups at same day, while capital letters $(\mathrm{A}, \mathrm{B}, \mathrm{C})$ indicate the difference within same group at different days.

Table 4. Huanglongbing symptomatic citrus plants after foliar application of Bacillus subtilis L1-21 and Hoagland solution.

\begin{tabular}{|c|c|c|c|c|c|c|c|c|c|}
\hline \multirow[b]{2}{*}{$\mathrm{Sr}$} & \multirow{2}{*}{$\begin{array}{l}\text { Treatment } \\
\text { Name }\end{array}$} & \multicolumn{2}{|c|}{0 Day } & \multicolumn{2}{|c|}{20 Day } & \multicolumn{2}{|c|}{40 Day } & \multicolumn{2}{|c|}{60 Day } \\
\hline & & $\mathrm{CT}$ & $\begin{array}{l}\text { Pathogen } \\
\text { Abundance }\end{array}$ & $\mathrm{CT}$ & $\begin{array}{l}\text { Pathogen } \\
\text { Abundance }\end{array}$ & $\mathrm{CT}$ & $\begin{array}{l}\text { Pathogen } \\
\text { Abundance }\end{array}$ & $\mathrm{CT}$ & $\begin{array}{c}\text { Pathogen } \\
\text { Abundance }\end{array}$ \\
\hline $\mathrm{T} 1$ & $\begin{array}{l}50 \% \text { Hoagland } \\
\text { solution }\end{array}$ & $23.90 \pm 0.018$ & $4.18 \times 10^{4}$ & $24.59 \pm 0.015$ & $2.94 \times 10^{4}$ & $24.32 \pm 0.014$ & $2.47 \times 10^{4}$ & $24.38 \pm 0.011$ & $2.45 \times 10^{4}$ \\
\hline $\mathrm{T} 2$ & $\begin{array}{l}50 \% \text { HS + B. } \\
\text { subtilis L1-21 }\end{array}$ & $21.06 \pm 0.015$ & $9.51 \times 10^{5}$ & $22.28 \pm 0.007$ & $1.35 \times 10^{5}$ & $23.04 \pm 0.005$ & $8.25 \times 10^{4}$ & $25.57 \pm 0.088$ & $1.06 \times 10^{4}$ \\
\hline T3 & B. subtilis L1-21 & $23.13 \pm 0.016$ & $8.17 \times 10^{4}$ & $24.47 \pm 0.005$ & $3.04 \times 10^{4}$ & $24.95 \pm 0.002$ & $2.29 \times 10^{4}$ & $28.12 \pm 0.002$ & $2.08 \times 10^{3}$ \\
\hline $\mathrm{T} 4$ & $\mathrm{ddH}_{2} \mathrm{O}(\mathrm{Ck})$ & $22.08 \pm 0.012$ & $1.92 \times 10^{5}$ & $22.25 \pm 0.005$ & $1.58 \times 10^{5}$ & $22.84 \pm 0.013$ & $1.08 \times 10^{5}$ & $22.26 \pm 0.007$ & $1.39 \times 10^{5}$ \\
\hline
\end{tabular}

$\mathrm{CT}=$ Threshold cycle. HS = Hoagland solution. Pathogen abundance in each sample were calculated using the standard curve used in our previous study [27]. Every treatment consists of three replications and each replicates consist of 3 citrus plants (3 years old).

\section{Discussion}

Endophyte-mediated control of citrus HLB is a serious challenge for saving the citrus industry globally [27]. Disruption of vascular function, loss of root mass, and altered mineral nutrition in HLB-affected trees lead to arrested tree and fruit growth, increased fruit drop, a decline in production, and could eventually lead to tree death [28,29]. Currently, HLB causes $90 \%$ production loss in commercial citrus orchards [30]. During past several years, many citrus growers have been documented to use nutrient management strategies for enhancing citrus production in HLB- affected trees [31], while the role of endophytic 
bacteria in plant disease control is to assist the plant to uptake nutrients, improve stress tolerance and provide disease resistance [20,21].

As previous studies proved that $B$. subtilis isolated from healthy chestnut trees have shown strong antagonistic activity against Cryphonectria parasitica, a causal organism of chestnut blight [32]. Different endophytic bacteria B. amyloliquefaciens, B. subtilis and B. pumilus reported as producers of several antibiotics (surfactin, iturin, bacillomucine; azalomycin F, surfactin, arthrobactin; surfactin, amphomycin, arthrobactin and valinomycin) which are highly inhibitory to the growth of X. campestris pv. campestris [33]. Bacillus subtilis was reported as a biocontrol agent against bacterial blight of rice through seedling dip, soil and foliar application [34]. Bacillus subtilis QST 713 is a commercialized bacterial strain used in biocontrol programs around the world [35]. As reported previously, there is always some high competition among nutrients in the plant that can negatively affect each other [36,37]. The citrus plant which was highly infected by HLB, has recovered after 60 days of foliar application of B. subtilis L1-21. Our main focus in this study was to check whether nutrients application could have any reduction of pathogen or increase population of endophytes. We showed the number of endophytes were constant applying different concentrations. Low and high trends of endophytes were present indicating that nutrients may have any direct role in activating the role of other endophytes that can reduce the pathogen inside, but how the interaction takes place still needs to be verified in detail through molecular mechanisms.

Based on overall literature, the present study was designed to check the Hoagland solution and endophyte dynamics in citrus plants during inoculation of isolated endophyte $B$. subtilis L1-21. In our knowledge, it is the first time Hoagland solution was applied on citrus plants with combination of endophyte B. subtilis L1-21 to find relationship of nutritional application and biocontrol strategy for reduction of CLas titer. The Hoagland solution provides every essential nutrient required by green plants and is appropriate for supporting growth of a large variety of plant species [38]. It consists of high concentrations of $\mathrm{N}$ and $\mathrm{K}$, which make it useful as a hydroponic nutrient solution for the development of large plants like tomato and bell pepper [39]. Firstly, we have applied Hoagland solution for citrus shoots by hydroponic method to find out the role of nutrients in endophytes colonization. Initial findings of the study showed that Hoagland solution with $50 \%$ concentration has shown good compatibility with colonization of indigenous endophytes inside leaves of citrus shoots. We suggested increase endophyte dynamics inside citrus plants, and higher level could not show any positive or negative effect on native endophytes.

Macro-and micro-nutrients can further improve plant disease resistance against $C$ Las pathogen indirectly through modification of microbial communities [40]. Plant microbiomes are the key agents involved in plant disease resistance [41]. Thereby, enhanced micronutrient fertilization could be used to improve plant growth in the presence of pathogen. In addition, micronutrients can trigger a systemic acquired resistance in plants, so they would work as elicitors to reduce disease loses, and also inhibit the pathogen colonization [42]. Specific function of different micronutrients in reduction of CLas titer specially, Zn can reduce bacterial infection. Mn is a key component for non-structural carbohydrate formation, for $\mathrm{N}$ metabolism, and for phenols and phytoalexin production, and finally, $\mathrm{Cu}$ has been used since the nineteenth century to reduce phytosanitary issues caused by microorganisms [43]. Taking together, we suggested that increasing micronutrient concentrations in diseased plants through both foliar and soil application could reduce HLB loses in citrus trees.

As previous studies, endophyte B. thuringiensis and B. subtilis (S-12) was reported as biocontrol of citrus canker caused by X. axanopodis pv. citri [44]. Same as, we also proved that $B$. subtilis L1-21 have antagonistic activity against $X$. citri subsp. citri. Endophytes with and without combination of Hoagland solution were further applied on HLB-affected citrus leaves by half-leaf method. Our study proved that B. subtilis L1-21 with combined treatment of Hoagland solution have shown maximum reduction of CLas titer. This endophytic bacterial strain along with the nutrient can possibly manage pathogen within 
weeks, but more time is required to get more results, as this pathogen is slow growing inside citrus plants, making the research difficult to handle inside citrus plants.

Furthermore, in order to get a clearer picture of using these endophytes, B. subtilis L121 with combined application of Hoagland solution was applied on HLB asymptomatic and symptomatic citrus plants. We concluded that the number of pathogen abundance reduced with an increasing number of endophytes. Maximum disease reduction was observed in HLB symptomatic plants by treatment of B. subtilis L1-21, and combined treatment of Hoagland solution with B. subtilis L1-21 in HLB asymptomatic plants displayed remarkable changes in CLas titer. Overall, comparison of Hoagland with endophyte application in asymptomatic and symptomatic citrus plants revealed clear difference, with maximum number of pathogen reduction was noted in former and slight pathogen reduction in later plants. We suggested that Hoagland solution could helpful in asymptomatic plants by providing nutrients and improving growth structure.

Importantly, restructuring the diseased host in the presence of inoculated endophytes with nutrients can displayed marked changes in citrus host, as our results revealed that endophyte application along with nutrients results in reduction of pathogen and same time the number of endophytes also reached to remarkable level. Often researchers do not see improvement in growth or yield of HLB-affected trees in only 1 to 2 years of HLB-nutrition research [45]. This suggests that HLB-nutrition research, like healthy citrus research, should be conducted for longer durations to appropriately evaluate the treatments, particularly with large, mature trees. Still, a lot of research has been used to mimic the spread of HLB disease in citrus groves, and there are still doubts about the contribution of such strategies to minimize the losses caused by the disease in the citrus industry.

Zambon et al. [46] reported beneficial effects of Mn foliar application with three times higher than the recommended dose in HLB-affected trees have shown reduction of CLas titer and improvement of fruit production $[46,47]$. Therefore, it can be proven that nutrients have great importance in the interaction of the plant host, microbial community and vectors [14,46,48]. Most of essential nutrients influenced the severity of plant disease [49]. It seems that nutrient elements could reduce the severity of disease symptoms, yet there are many findings on both sides of this debate [50].

Nutrient application via foliar sprays or soil drenching reported as another tool to protect HLB-affected trees [51]. Soil fertility and observing exact plant nutritional status is a key strategy to fulfill the plant desire. It is very important for citrus grower to have grip on knowledge of proper dosses of fertilizer application and timing for better plant growth. By enhanced nutritional programs, citrus HLB-affected trees can also survive and increase fruit production [11]. There is an interesting approach for better fruit production in the presence of disease by proper irrigation, best cultural practices and maintaining nutritional requirements through foliar and soil drenching techniques [52].

\section{Materials and Methods}

\subsection{Bacterial Strains, Culture Conditions, and Citrus Plants}

The candidate bacterial endophytes Bacillus subtilis YN-003, B. subtilis YN-012, B. spizizenii YN-016, B. subtilis YN-024, and B. subtilis YN-033 were isolated from healthy citrus plants (Citrus limon, Citrus sinensis) and cultured on Luria Bertani (LB; Bacto tryptone $10 \mathrm{~g} / \mathrm{L}$, yeast extract $5 \mathrm{~g} / \mathrm{L}, \mathrm{NaCl} 5 \mathrm{~g} / \mathrm{L}$, agar $18 \mathrm{~g} / \mathrm{L}$, and pH 7.0) and Tryptic Soya Agar (TSA) media. Bacillus subtilis L1-21 was previously isolated as a potential indigenous endophyte from healthy citrus plants [25]. Healthy citrus shoots (Citrus Limon) were collected from citrus plants grown in pots in a greenhouse of State Key Laboratory for Conservation and Utilization of Bio-resources Kunming, China.

\subsection{Effect of Hoagland Solution on Endophytes Population in Citrus Shoots}

Hoagland solution was prepared according to the designed formula of Hoagland and Arnon in 1938 which was revised by Arnon in 1950 [53]. Indigenous endophytes were isolated from citrus leaf through surface sterilization with $75 \%$ ethanol for $30 \mathrm{~s}$, 
followed by $\mathrm{NaClO}$ for $1 \mathrm{~min}$. Leaves were ground in a sterilized pestle and mortar, followed by three series of dilutions $\left(10^{-1}, 10^{-2}\right.$ or $\left.10^{-3}\right)$. Furthermore, $100 \mu \mathrm{L}$ of suspension was taken from $10^{-3}$ dilution and spread on LB agar and incubated at $30{ }^{\circ} \mathrm{C}$ for $48 \mathrm{~h}[51,52]$. Endophyte colonies were counted and identified on morphological basis. Different concentrations of Hoagland solution (50\%, 75\% and 100\%) were treated to check the efficacy for maximum number of endophytes colonization. Citrus shoots treated with $\mathrm{ddH}_{2} \mathrm{O}$ serve as control. Initially, leaf samples were collected before application, followed by 2 days interval with the presence of Hoagland solution to check endophyte population dynamics inside citrus leaves.

\subsection{Antagonistic Effect of Candidate Bacillus strains against Xanthomonas citri subsp. citri}

Different endophytes (50 strains) were isolated and identified on the basis of morphological characters. These endophytes were further cultured on TSA (Tryptic soy agar) liquid media and incubated in shaker at $30{ }^{\circ} \mathrm{C}$ for $16 \mathrm{~h}$, all of these isolates were tested on TSA media plates for confirmation of biocontrol activity. Due to non-culturable characteristics of pathogen Candidatus Liberibactor asiaticus, surrogate pathogen was used to test candidate endophytes in lab experiments. Xanthomonas citri subsp. citri was used as pathogenic bacteria with dilution of $10^{-1}$ and concentration of $200 \mu \mathrm{L}$ was spread on TSA agar media plates. After $15 \mathrm{~min}$ of inoculating $X$. citri subsp. citri, $5 \mu \mathrm{L}$ culture of each isolated strain were punched on the plate by pipetting followed by incubation for $48 \mathrm{~h}$ at $28{ }^{\circ} \mathrm{C}$. The experiment was repeated four times. Diameter of bacterial inhibition zones was measured and suppression efficiency of isolates were evaluated. In addition, the bacterial isolates with maximum inhibition zones were tested again against pathogen. Antagonistic activity was expressed as the growth inhibition ratio (GIR) by using the following formula.

$$
\text { GIR }=[(\text { Inhibition zone diameter }- \text { colony diameter }) / \text { inhibition zone }] \times 100
$$

\subsection{Effect of Different Bacillus sp. on Number of Pathogen Abundance of CLas Using} Half-Leaf Method

Diseased leaves were selected from HLB-affected citrus plants grown under greenhouse of Yunnan Agricultural University, China and confirmed through qPCR using primer sequence CQULA04F 5' TGGAGGTGTAAAAGTTGCCAAA 3', CQULA04R 5' CCAACGAAAAGATCAGATATTCCTCTA $3^{\prime}$. Half leaf methods were applied as designed by Munir et al. [24], with some modifications. Leaves were further treated with different candidate endophytes. Leaves were cut into two parts; a half part was firstly analyzed for checking number of pathogen abundance through qPCR before treatment of endophytes. Different Bacillus strains (B. subtilis YN-003, B. subtilis YN-012, B. spizizenii YN-016, B. subtilis YN-033 and $B$. subtilis L1-21) with and without Hoagland solution and $\mathrm{Ck}\left(\mathrm{ddH}_{2} \mathrm{O}\right)$ were treated on half parts of leaves to check efficacy of endophytes and Hoagland solution in reduction of CLas titer. Hoagland solution was prepared as described above. For DNA extraction, midribs of leaves were cut and frozen in liquid nitrogen, followed by midribs of 5 leaves from one tree were pooled and macerated in a sterile pestle and mortar. DNA of leaf samples was extracted using the method described by Munir et al. [27] with slight modifications. The CLas pathogen was detected using SYBER Green reagent, and the PCR reaction was performed in a $20 \mu \mathrm{L}$ reaction mixture containing 1xPCR buffer (SYBER Green Master Mix; Bio-Red, Hercules, CA, USA); $0.8 \mu \mathrm{L}$ of CQULA04R and CQULA04F primer and DNA template required for reaction. Detection of HLB pathogen through qPCR was checked by followed method described with slight modification [27].

\subsection{Effect of Hoagland Solution + Bacillus subtilis L1-21 on HLB Asymptomatic Citrus Plants}

HLB asymptomatic citrus plants which were grown under greenhouse of Yunnan Agricultural University, Kunming, China was selected for application of different treatments. Four treatments (50\% Hoagland solution, 50\% Hoagland solution + B. subtilis L1-21, B. subtilis L1-21 and $\mathrm{ddH}_{2} \mathrm{O}$ ) with three replications were applied to check the control effect on CLas titer in citrus plants. Leaf samples were collected before and after 20,40, and 
60 days of treatment. Leaf samples were placed in a cool box with ice and brought to the laboratory for isolation of endophytes. DNA extraction and real-time qPCR analysis was performed as mentioned above. Isolation of endophytes and pathogen abundance were checked through previous method as described above.

\subsection{Effect of Hoagland Solution + Bacillus subtilis L1-21 on HLB Symptomatic Citrus Plants}

HLB-affected citrus plants (C. lemon) were selected which were grown under greenhouse of Yunnan Agricultural University, Kunming, China. Four treatments (50\% Hoagland solution, 50\% Hoagland solution+ B. subtilis L1-21, Bacillus subtilis L1-21 and dd $\mathrm{H}_{2} \mathrm{O}$ ) with three replications were applied to check the control effect on CLas titer in citrus plants. Leaf samples were collected before and after 20,40, and 60 days of treatment. The samples were placed in a cool box with ice and brought to the laboratory for isolation of endophytes. DNA extraction, qPCR for pathogen abundance, and endophytes isolation were evaluated as described above.

\subsection{Statistical Analysis}

All the experiments were conducted with three replicates in each treatment. The data were statistically analyzed using analysis of variances (ANOVA) in IBM SPSS Statistics 23 , the means were subjected to Duncan's multiple range test at $p \leq 0.05$. All figures were processed and analyzed using Adobe Illustrator CS5 (Adobe Systems Inc., San Francisco, CA, USA) and GraphPad Prism (8.0.2).

\section{Conclusions}

Here, we describe that endophyte B. subtilis L1-21 in the presence of nutrient solution has noticeable effect on pathogen reduction inside diseased citrus plants. However, the complex interactions need to be uncovered in more detail. Series of events performed in this study are mentioned in summarized sketch in Figure 4. Hoagland solution as a nutrient source could change plant structure in asymptomatic plants. In addition, we found that micro-nutrients alone could not make enough difference to the reduction of pathogen, and pathogen numbers were stable. Remarkable consistency of these endophytes present in citrus is due to the time interval of endophytes check. It was also concluded that CLas reduction has an inverse relationship with B. subtilis L1-21 colonization. Citrus endophytes are suggested as environmentally friendly control strategies, which can potentially strengthen the native microbial diversity of citrus plants and finally overcome pathogen spread. 


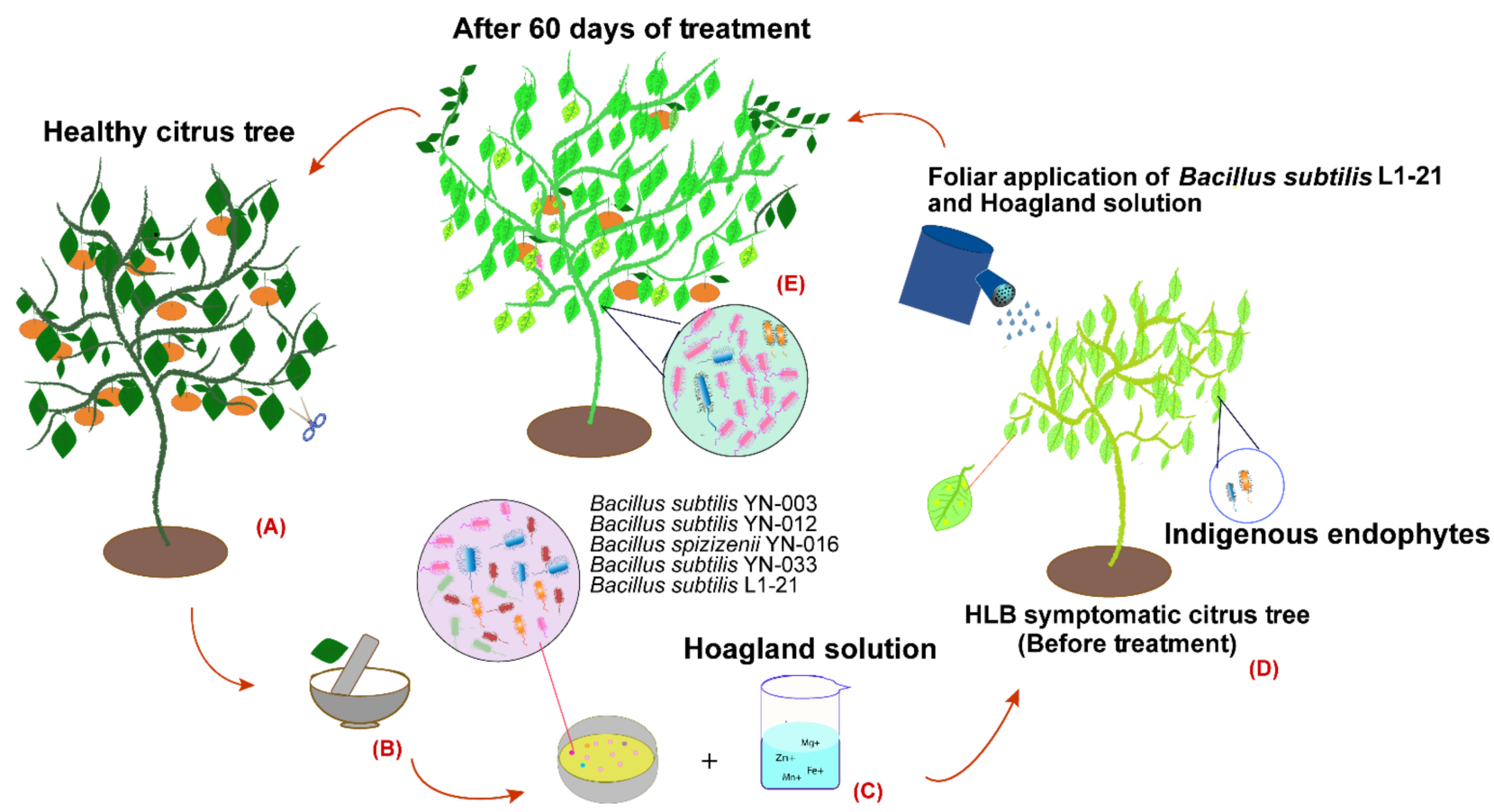

Figure 4. Concluding sketch of experiments performed in this study. (A) Healthy citrus tree. (B) Isolation of indigenous endophytic bacteria from leaves of healthy citrus tree. (C) Colony growth of different endophytic bacteria. (D) Foliar application of Bacillus subtilis L1-21 with combination of Hoagland solution on HLB-symptomatic citrus tree. (E) After 60 days of continuous treatment, citrus tree became healthy with reduce number of CLas pathogen.

Author Contributions: Conceptualization, S.A., P.H. (Pengbo He), P.H. (Pengfei He), Y.L., Y.W. (Yixin Wu), A.A., Y.W. (Yunyue Wang), S.M. and Y.H.; methodology, S.A., P.H. (Pengbo He), P.H. (Pengfei He) and S.M.; software, S.A., Y.L. and A.A.; validation, S.A., Y.W (Yixin Wu) and A.A.; formal analysis, S.A., A.A. and Y.W. (Yunyue Wang); investigation, S.A. and Y.L.M.; resources, Y.H., Y.W. (Yixin Wu), and Y.W. (Yunyue Wang); data curation, S.A. and Y.L.; writing-original draft preparation, S.A., P.H. (Pengbo He), S.M. and A.A.; writing-review and editing, S.M., A.A. and Y.H.; visualization, S.M. and Y.H.; supervision, Y.H.; project administration, P.H. (Pengbo He), P.H. (Pengfei He), S.M. and Y.H. All authors have read and agreed to the published version of the manuscript.

Funding: This research was financially supported by National Natural Science Foundation of China (32050410307), Central Government Fund for Local Science and Technology Development (202107AA110007), China Postdoctoral Science Foundation (No. 2020M683664XB), and Yunnan First Level Research Fund for Post-doctorate Researchers (202103), Yunnan Oriental Training Program Funding for Post-doctorate researchers (No. YN2020409; YN2020410).

Institutional Review Board Statement: Not applicable.

Informed Consent Statement: Not applicable.

Data Availability Statement: All the data is present inside manuscript file.

Conflicts of Interest: The authors declare no conflict of interest.

\section{References}

1. Huang, C.Y.; Araujo, K.; Sánchez, J.N.; Kund, G.; Trumble, J.; Roper, C.; Godfrey, K.E.; Jin, H. A stable antimicrobial peptide with dual functions of treating and preventing citrus Huanglongbing. PNAS. 2021, 118, 1. [CrossRef] [PubMed]

2. Bové, J.M. Huanglongbing: A destructive, newly-emerging, century-old disease of citrus. J. Plant Pathol. 2006, 88, 7-37.

3. Bove, J.M.; Ayres, A.J. Etiology of three recent diseases of citrus in Sao Paulo State: Sudden death, variegated chlorosis and huanglongbing. IUBMB Life 2007, 59, 346-354. [CrossRef] [PubMed]

4. Gottwald, T.R. Current epidemiological understanding of citrus huanglongbing. Annu. Rev. Phytopathol. 2010, 48, 119-139. [CrossRef]

5. Aritua, V.; Achor, D.; Gmitter, F.G.; Albrigo, G.; Wang, N. Transcriptional and microscopic analyses of citrus stem and root responses to Candidatus Liberibacter asiaticus infection. PLoS ONE 2013, 8, e73742. [CrossRef] 
6. Morgan, K.T.; Rouse, R.E.; Ebel, R.C. Foliar applications of essential nutrients on growth and yield of 'Valencia'sweet orange infected with Huanglongbing. HortScience 2016, 51, 1482-1493. [CrossRef]

7. Li, W.; Hartung, J.S.; Levy, L. Quantitative real-time PCR for detection and identification of Candidatus Liberibacter species associated with citrus huanglongbing. J. Microbiol. Methods 2006, 66, 104-115. [CrossRef]

8. Braswell, W.E.; Park, J.-W.; Stansly, P.A.; Kostyk, B.C.; Louzada, E.S.; da Graça, J.V.; Kunta, M.J.S.R. Root samples provide early and improved detection of Candidatus Liberibacter asiaticus in citrus. Sci. Rep. 2020, 10, 16982. [CrossRef]

9. Etxeberria, E.; Gonzalez, P.; Achor, D.; Albrigo, G. Anatomical distribution of abnormally high levels of starch in HLB-affected Valencia orange trees. Physiol. Mol. Plant Pathol. 2009, 74, 76-83. [CrossRef]

10. Razi, M.; Khan, I.A.; Jaskani, M.J. Citrus plant nutritional profile in relation to Huanglongbing prevalence in Pakistan. Pak. J. Agric. Sci. 2011, 48, 299-304.

11. Gottwald, T.; Graham, J.; Irey, M.; McCollum, T.; Wood, B.W. Inconsequential effect of nutritional treatments on huanglongbing control, fruit quality, bacterial titer and disease progress. Crop Prot. 2012, 36, 73-82. [CrossRef]

12. Zhao, H.; Sun, R.; Albrecht, U.; Padmanabhan, C.; Wang, A.; Coffey, M.D.; Girke, T.; Wang, Z.; Close, T.J.; Roose, M. Small RNA profiling reveals phosphorus deficiency as a contributing factor in symptom expression for citrus huanglongbing disease. Mol. Plant 2013, 6, 301-310. [CrossRef]

13. Tian, S.; Lu, L.; Labavitch, J.M.; Webb, S.M.; Yang, X.; Brown, P.H.; He, Z. Spatial imaging of Zn and other elements in Huanglongbing-affected grapefruit by synchrotron-based micro X-ray fluorescence investigation. J. Exp. Bot. 2014, 65, 953-964. [CrossRef]

14. Cakmak, I.; Kirkby, E.A. Role of magnesium in carbon partitioning and alleviating photooxidative damage. Physiol. Plant. 2008, 133, 692-704. [CrossRef]

15. Marschner, H. Marschner's Mineral Nutrition of Higher Plants; Academic Press: Cambridge, MA, USA, 2011.

16. Martinelli, F.; Uratsu, S.; Albrecht, U.; Reagan, R.; Phu, M.; Britton, M.; Buffalo, V.; Fass, J.; Leicht, E.; Zhao, W.D.; et al. Transcriptome profiling of citrus fruit response to huanglongbing disease. PLoS ONE 2012, 7, e38039. [CrossRef]

17. Sun, S.-s.; Chen, X.-m.; Guo, S.-x. Analysis of endophytic fungi in roots of Santalum album Linn. and its host plant Kuhnia rosmarinifolia vent. J. Zhejiang Univ. Sci. B 2014, 15, 109-115. [CrossRef]

18. Munir, S.; Ahmed, A.; Li, Y.; He, P.; Singh, B.; He, P.; Li, X.; Asad, S.; Wu, Y.; He, Y. The hidden treasures of citrus: Finding huanglongbing cure where it was lost. Crit. Rev. Biotechnol. 2021, 1, 1-16. [CrossRef]

19. Singh, B.K.; Trivedi, P.; Egidi, E.; Macdonald, C.A.; Delgado-Baquerizo, M. Crop microbiome and sustainable agriculture. Nat. Rev. Microbiol. 2020, 18, 601-602. [CrossRef]

20. Ryan, R.P.; Germaine, K.; Franks, A.; Ryan, D.J.; Dowling, D.N. Bacterial endophytes: Recent developments and applications. FEMS Microbiol. Lett. 2008, 278, 1-9. [CrossRef]

21. Hamilton, C.E.; Gundel, P.E.; Helander, M.; Saikkonen, K. Endophytic mediation of reactive oxygen species and antioxidant activity in plants: A review. Fungal Div. 2012, 54, 1-10. [CrossRef]

22. Ahmed, A.; Munir, S.; He, P.; Li, Y.; He, P.; Yixin, W.; He, Y. Biocontrol arsenals of bacterial endophyte: An imminent triumph against clubroot disease. J. Microbiol. Res. 2020, 241, 126565. [CrossRef]

23. Wang, M.; Xing, Y.; Wang, J.; Xu, Y.; Wang, G. The role of the chi1 gene from the endophytic bacteria Serratia proteamaculans 336x in the biological control of wheat take-all. Can. J. Microbiol. 2014, 60, 533-540. [CrossRef]

24. Munir, S.; Li, Y.; He, P.; He, P.; He, P.; Cui, W.; Wu, Y.; Li, X.; Li, Q.; Hua, X. Restructuring citrus endophytic diversity through potential indigenous endophytes could eliminate huanglongbing pathogen Candidatus Liberibacter asiaticus. Res. Sq. 2020, 1-26. [CrossRef]

25. Munir, S.; Li, Y.; He, P.; He, P.; Ahmed, A.; Wu, Y.; He, Y. Unraveling the metabolite signature of citrus showing defense response towards Candidatus Liberibacter asiaticus after application of endophyte Bacillus subtilis L1-21. Microbiol. Res. 2020, 234, 126425. [CrossRef]

26. Bu, S.; Munir, S.; He, P.; Li, Y.; Wu, Y.; Li, X.; Kong, B.; He, P.; He, Y. Bacillus subtilis L1-21 as a biocontrol agent for postharvest gray mold of tomato caused by Botrytis cinerea. Biol. Control 2021, 157, 104568. [CrossRef]

27. Munir, S.; Li, Y.; He, P.; Huang, M.; He, P.; He, P.; Cui, W.; Wu, Y.; He, Y. Core endophyte communities of different citrus varieties from citrus growing regions in China. Sci. Rep. 2020, 10, 3648. [CrossRef]

28. Halbert, S.E.; Manjunath, K.L. Asian citrus psyllids (Sternorrhyncha: Psyllidae) and greening disease of citrus: A literature review and assessment of risk in Florida. Fla. Entomol. 2004, 87, 330-353. [CrossRef]

29. Tang, L.; Chhajed, S.; Vashisth, T. Preharvest fruit drop in Huanglongbing-affected 'Valencia' sweet orange. J. Am. Soc. Hortic. Sci. 2019, 144, 107-117. [CrossRef]

30. Singerman, A. The real cost of HLB in Florida. Citrus Ind 2019, 2019, 10-13.

31. Vashisth, T.; Grosser, J. Comparison of controlled release fertilizer (CRF) for newly planted sweet orange trees under Huanglongbing prevalent conditions. J. Hort. 2018, 5, 244-249. [CrossRef]

32. Wilhelm, E.; Arthofer, W.; Schafleitner, R.; Krebs, B. Bacillus subtilis an endophyte of chestnut (Castanea sativa) as antagonist against chestnut blight (Cryphonectria parasitica). Plant Cell Tissue Organ C. 1998, 52, 105-108. [CrossRef]

33. Wulff, E.G.; Mguni, C.M.; Mortensen, C.N.; Keswani, C.L.; Hockenhull, J. Biological control of black rot (Xanthomonas campestris pv. campestris) of brassicas with an antagonistic strain of Bacillus subtilis in Zimbabwe. Eur. J. Plant Pathol. 2002, 108, 317-325. [CrossRef] 
34. Nagendran, K.; Karthikeyan, G.; Peeran, M.F.; Raveendran, M.; Prabakar, K.; Raguchander, T. Management of bacterial leaf blight disease in rice with endophytic bacteria. World Appl. Sci. J. 2013, 28, 2229-2241.

35. Abbasi, P.A.; Weselowski, B. Influence of foliar sprays of Bacillus subtilis QST 713 on development of early blight disease and yield of field tomatoes in Ontario. Can. J. Plant Pathol. 2014, 36, 170-178. [CrossRef]

36. Hall, J.á; Williams, L.E. Transition metal transporters in plants. J. Exp. Bot. 2003, 54, 2601-2613. [CrossRef]

37. Hippler, F.; Boaretto, R.; Quaggio, J.; Azevedo, R.; Mattos, D., Jr. Towards soil management with Zn and Mn: Estimates of fertilisation efficacy of citrus trees. Ann. Appl. Biol. 2015, 166, 484-495. [CrossRef]

38. Smith, K.P.; Goodman, R.M. Host variation for interactions with beneficial plant-associated microbes. Annu. Rev. Phytopathol. 1999, 37, 473-491. [CrossRef]

39. He, F.; Thiele, B.; Watt, M.; Kraska, T.; Ulbrich, A.; Kuhn, A. Effects of root cooling on plant growth and fruit quality of cocktail tomato during two consecutive seasons. J. Food Qual. 2019, 2019, 3598172. [CrossRef]

40. Zhou, Y.; Tang, Y.; Hu, C.; Zhan, T.; Zhang, S.; Cai, M.; Zhao, X. Soil applied Ca, Mg and B altered Phyllosphere and Rhizosphere bacterial microbiome and reduced Huanglongbing incidence in Gannan Navel Orange. Sci. Total Environ. 2021, 791, 148046. [CrossRef]

41. Laforest-Lapointe, I.; Paquette, A.; Messier, C.; Kembel, S.W. Leaf bacterial diversity mediates plant diversity and ecosystem function relationships. Nat. Rev. Microbiol. 2017, 546, 145-147. [CrossRef]

42. Fones, H.; Preston, G.M. The impact of transition metals on bacterial plant disease. FEMS Microbiol. Rev. 2013, 37, 495-519. [CrossRef]

43. Russell, P. A century of fungicide evolution. J. Agric. Sci. 2005, 143, 11-25. [CrossRef]

44. Das, R.; Mondal, B.; Mondal, P.; Khatua, D.; Mukherjee, N. Biological management of citrus canker on acid lime through Bacillus subtilis (S-12) in West Bengal, India. J. Biopestic. 2014, 7, 38.

45. Rouse, R.E.; Ozores-Hampton, M.; Roka, F.M.; Roberts, P. Rehabilitation of Huanglongbing-affected citrus trees using severe pruning and enhanced foliar nutritional treatments. HortScience 2017, 52, 972-978. [CrossRef]

46. Zambon, F.T.; Kadyampakeni, D.M.; Grosser, J.W. Ground application of overdoses of manganese have a therapeutic effect on sweet orange trees infected with Candidatus Liberibacter asiaticus. HortScience 2019, 54, 1077-1086. [CrossRef]

47. Hippler, F.W.R.; Petená, G.; Boaretto, R.M.; Quaggio, J.A.; Azevedo, R.A.; Mattos, D., Jr. Mechanisms of copper stress alleviation in citrus trees after metal uptake by leaves or roots. Environ. Sci. Pollut. Res. 2018, 25, 13134-13146. [CrossRef]

48. Da Silva, J.R.; de Alvarenga, F.V.; Boaretto, R.M.; Lopes, J.R.S.; Quaggio, J.A.; Coletta Filho, H.D.; Mattos, D. Following the effects of micronutrient supply in HLB-infected trees: Plant responses and 'Candidatus Liberibacter asiaticus' acquisition by the Asian citrus psyllid. Trop. Plant Pathol. 2020, 45, 597-610. [CrossRef]

49. Dordas, C. Role of nutrients in controlling plant diseases in sustainable agriculture. A review. Agron. Sustain. Dev. 2008, 28, 33-46. [CrossRef]

50. Huber, D.M.; Jones, J.B. The role of magnesium in plant disease. Plant Soil 2013, 368, 73-85. [CrossRef]

51. Mendis, H.C.; Ozcan, A.; Santra, S.; De La Fuente, L. A novel Zn chelate (TSOL) that moves systemically in citrus plants inhibits growth and biofilm formation of bacterial pathogens. PLOS ONE 2019, 14, e0218900. [CrossRef]

52. Ferrarezi, R.S.; Wright, A.L.; Boman, B.J.; Schumann, A.W.; Gmitter, F.G.; Grosser, J.W.J.H. Protected fresh grapefruit cultivation systems: Antipsyllid screen effects on plant growth and leaf transpiration, vapor pressure deficit, and nutrition. HortTechnology 2017, 27, 666-674. [CrossRef]

53. Hoagland, D.R.; Arnon, D.I. The water-culture method for growing plants without soil. Circ. Calif. Agric. Exp. Stn. 1950, $347,32$. 